PROPOSAL RISET

\title{
STUDI FENOMENOLOGI PENGALAMAN PERAWAT DALAM MEMBERIKAN ASUHAN KEPERAWATAN PADA PASIEN KRITIS DI RUANG INTENSIF
}

\author{
Setiyo Adi Nugroho
}

Universitas Nurul Jadid, setiyo@unuja.ac.id

\begin{abstract}
Ringkasan
Bekerja di ruang intensif dapat menjadi trauma bagi tenaga keperawatan. Perawat ruang intensif berulangkali dihadapkan dengan keadaan kritis dan kematian pasien. Seringkali juga terlibat dalam merawat pasien dengan keadaan terminal, yang dimana kemungkinan pasien meninggal. Berbagai upaya perawat menghadapi permasalahan yang komplek di ruang intensif. Penelitian kualitatif dengan pendekatan fenomenologi ini bertujuan memperoleh informasi yang mendalam tentang pengalaman perawat dalam memberikan asuhan keperawatan dengan kondisi pasien krirtis di ruang intensif. Studi kualitatif dengan pendekatan fenomenologi digunakan dalam studi ini. Partisipan akan dipilih sesuai dengan kreteria penelitian, wawancara mendalam setelah mendapat persetujuan dari partisipan. Wawancara formal tidak berstruktur akan dilakukan sebanyak dua kali dan selanjutnya dilakukan analisa dengan teknik analisis spesifik dengan menggunakan pendekatan analisis selektif dan focusing.
\end{abstract}

Kata kunci: Perawat, Kritis, Ruang Intensif 


\section{Bab 1}

Pendahuluan

\section{Latar Belakang}

Akhir dari kehidupan adalah kematian, tidak akan bisa dihindari kematian bagi setiap manusia. Di Amerika Serikat, sekitar 2,5 juta orang meninggal setiap tahunnya, lebih dari $60 \%$ dari kematian ini terjadi di rumah sakit, dan setengah dari kematian tersebut terjadi di perawatan ICU (Espinosa, Young, Symes, Haile, \& Walsh, 2010). Sehingga, di Amerika Serikat menjadi perhatian yang paling utama dalam memberikan perawatan yang tepat bagi pasien kritis di rumah sakit (Kirchhoff et al., 2000).

Angka kematian diruang Intensif berkisar dari 15 sampai 30\%, tergantung kasus yang terjadi. Selain itu, sekitar $20 \%$ pasien meninggal setelah keluar dari ruang ICU (Whiteley, Bodenham, \& Bellamy, 2010). Kematian yang terjadi diruang ICU bukanlah hal yang mudah, beberapa studi yang dikutip dari penelitian (Beckstrand \& Kirchhoff, 2005; Elpern, Covert, \& Kleinpell, 2005) melaporkan merawat pasien yang kritis dan pasien yang tidak bisa diharapkan kesembuhannya serta keluarga pasien menjadi factor stress bagi perawat dalam melakukan perawatan. Sementara itu, pemberi layanan kesehatan lainnya hanya berkunjung sesaat dan kemudian meninggalkan pasien.

Permasalahan kematian di ruang intensif begitu komplek. Salah satu diantaranya dikarenakan sterilisasi lingkungan, sehingga kematian di ruang Intensif menjadi kematian yang tidak berperasaan (Smith, 2000). Sementara menurut Dawson (2008) menyatakan bahwa tim perawatan kritis kurang siap dalam memberikan perawatan paliatif walaupun banyak pasien terminal yang memiliki gejala akut (Sibbald, Downar, \& Hawryluck, 2007). Dinyatakan oleh Faber-Langendoen dan Lanken (2000) Kurangnya perhatian perawatan paliatif care diruang intensif disebabkan Fokus perawatan di ruang intensif banyak digunakan dalam hal penyelamatan pasien (cure) seperti melakukan tindakan pemasangan ventilator dan resusitasi (Stevens, Jackson, \& Milligan, 2009). 
Perawatan ruang Intensif sering kali memberikan pengobatan yang sia-sia, dimana hanya sedikit harapan pasien dapat sembuh (Sibbald et al., 2007), Hadders (2007) menyatakan pengobatan yang sia-sia tersebut menyebabkan pasien meninggal dengan cara tidak bermartabat. Hal lainya juga, seringkali perawatan intensif melanggar integritas pasien dalam pengambilan keputusan medis (Stevens et al., 2009). Bukan hanya kepada pasien melainkan juga kepada keluarga pasien (Heyland, Rocker, O'Callaghan, Dodek, \& Cook, 2003; Kirchhoff et al., 2002).

Meninggal secara damai dan bermartabat merupakan tujuan utama dalam perawatan paliatif, untuk itu pentingnya asuhan keperawatan paliatif care di ruang intensif. Dalam melakukan perawatan paliatif di ruang Intensif, perawat sering mengalami konfik keyakinan sebagai penyedia layanan keperawatan mandiri dan advocad bagi pasien, dibandingkan peran perawat sebagai asisten yang hanya melaksanakan tindakan berdasarkan perintah dokter, pengalaman ini sering dialami dan dirasakan oleh perawat (Calvin, Lindy, \& Clingon, 2009). Berdasarkan sebuah studi (Beckstrand \& Kirchhoff, 2005; Elpern et al., 2005) Diantara petugas kesehatan yang lainnya, hanya perawat disamping pasien selama 24 jam, akan tetapi perawat merasakan distress moral dalam melakukan merawat pasien kritis. Tekanan moral perawat yang bekerja di unit perawatan intensif dianggap sebagai hal yang unik dan tidak proporsional dengan apa yang dialami perawat (Elpern et al., 2005).

Sejumlah penelitian telah melaporkan pengalaman-pengalaman perawat dalam memberikan asuhan perawatan paliatif di ruang intensif dari Negara Amerika dan Afrika selatan (Calvin et al., 2009; Espinosa et al., 2010; Kirchhoff et al., 2000; Naidoo \& MN, 2014). Sementara itu, di Indonesia masih sangat sedikit informasi tentang pengalaman perawat intensif dalam memberikan perawatan palitiatif diruang intensif. Sementara banyak penelitian keperawatan kepada pasien palliatif di lain ruang instensif, dengan berbagai permasalahan yang komplek diruang intensif tentunya berbeda dengan yang lain. 


\section{Rumusan Masalah}

Meneliti pengalaman perawat di ruang intensif dalam memberikan pelayanan perawatan paliatif pada pasien kritis sangatlah penting. Hal tersebut dikarenakan, bekerja di ruang intensif dapat menjadi trauma bagi tenaga keperawatan. Perawat ruang intensif berulangkali dihadapkan dengan keadaan kritis dan kematian pasien. Seringkali juga terlibat dalam merawat pasien dengan keadaan terminal, yang dimana kemungkinan pasien meninggal. Perawat ruang intensif seringkali mengalami stress dengan merawat pasien dengan keadaan kritis. Menurut Alspach (2006) ruang lingkup praktek keperawatan di ruang intensif diartikan adanya interaksi yang dinamis antara pasien dengan perawat, hal tersebut menyebabkan timbulnya emosi yang kuat seperti kemarahan, frustasi, ataupun tidak suka pada perawat (Naidoo \& MN, 2014).

Kematian dan keadaan kritis pasien menyebabkan gangguan psikologis yang kompleks bagi perawat. seringnya berurusan dengan isu-isu mengerikan dan menyedihkan seperti kematian pasien dan keadaan yang kritis pasien merupakan tantangan tersendiri. Dan juga perawat sering dihadapkan dengan perasaan belum optimalnya tindakan keperawatan mandiri yang dilakukan.

Selain itu, belum banyaknya penelitian yang dilakukan di Indonesia tentang pengalaman perawat dalam memberikan asuhan keperawatan pada pasien yang mengalami keadaan kritis di ruang intensif. Padahal sejumlah penelitian di Amerika dan Afrika Selatan menjadi perhatian penelitian. Akan tetapi lain daerah lain permasalahan, dikarenakan berlainan lingkungan social dan budaya. Oleh karena itu, masalah penelitian ini dirumuskan dengan dua pertanyaan, yaitu: 1) Apa pengalaman perawat dalam menghadapi kematian dan keadaan kritis pasien di ruang intensif ?. 2) Bagaimana tindakan tan perawat dalam menghadapi berbagai tantangan dalam memberikan asuhan keperawatan di ruang intensif?

\section{Tujuan}

1. Mendiskripsikan dan menginterpretasikan pengalaman-pengalaman serta apa yang terjadi pada perawat dalam memberikan asuhan keperawatan pada pasien dalam keadaan kritis di ruang intensif. 
2. Mengungkapkan arti dari pengalaman perawat tersebut dalam menjalani selama memberikan asuhan keperawatan.

3. Memahami kebutuhan perawat di ruang intensif dan bagaimana perawat dalam melaksanakan asuhan keperawatan ada pasien dalam keadaan kritis.

\section{Manfaat Penelitian}

Penelitian ini bermanfaat dalam memberikan wawasan, informasi dan pemahaman perawat khususnya perawat yang bertugas diruang intensif dalam memberikan asuhan keperawatan pada pasien dalam keadaan kritis atau iruang intensif. Pada gilirannya studi ini memberikan pemahaman yang lebih luas dan dalam bagi perawat kritis maupun medical bedah tentang apa yang terjadi sebenarnya pada perawat dalam memberikan asuhan keperawatan diruang intensif dan bagaimana persepsi perawat tentang pemberian asuhan keperawatan pasien dengan keadaan kritis atau menghadapi kematian diruang intensif. 


\section{Bab 2}

\section{Tinjauan Literatur}

Kematian dan pasien sekarat di ruang ICU merupakan fenomena yang universal. Kematian dan sekarat adalah proses yang tak terelakkan dalam lingkungan ICU. Pasien dirawat di ICU bisa mati dari berbagai diagnosa atau komplikasi tersebut. Kematian di ICU kadang-kadang dapat tak terduga, ketika pasien meninggal mendadak setelah trauma, setelah sakit yang berlangsung lama, penarikan dukungan hidup atau sebagai akibat dari kematian otak (Naidoo \& MN, 2014).

Penelitian yang dilakukan oleh Kirchhoff dan Beckstrand (2005) mengungkapkan bahwa sebagian besar pasien intensif, bergantung pada tenaga profesinal baik medis maupun paramedis untuk menjadi sumber kenyamanan dan informasi selama masa end of life. Penulis juga menyampaikan bahwa, tenaga medis maupun perawat merupakan komponen penting dalam perawatan end of life di ruang ICU (Beckstrand \& Kirchhoff, 2005). Kegiatan keperawatan di ICU menciptakan lingkungan yang penuh kasih, mendukung dan terapi untuk pasien, dengan tujuan utama adalah mempromosikan kenyamanan dan penyembuhan dan mencegah penderitaan yang tidak perlu.. Sehingga perawat berperan penting dalam pengambilan keputusan etis di ruang Instensif seperti meninggal dengan bermartabat, penghentian alat bantu hidup, dan masalah kualitas hidup pasien (Naidoo \& MN, 2014).

Kematian di ruang Intensif dikenal sebagai kematian yang tidak berperasaan dikarenakan sterilisasi lingkungan (Smith, 2000). Permasalahan lainnya yaitu perawatan ruang Intensif sering kali memberikan pengobatan yang sia-sia, dimana hanya sedikit harapan pasien dapat sembuh (Sibbald et al., 2007), Hadders (2007) menyatakan pengobatan yang sia-sia tersebut menyebabkan pasien meninggal dengan cara tidak bermartabat. Hal lainya juga, seringkali perawatan intensif melanggar integritas pasien dalam pengambilan keputusan medis (Stevens et al., 2009). Ada juga bukti dukungan yang buruk bagi keluarga pasien yang meninggal di ICU (Kirchhoff et al., 2002) dan seringkali mereka tidak sepenuhnya terlibat dalam pengambilan keputusan pengobatan. Bahkan penelitian yang dilakukan (Lind, Lorem, Nortvedt, \& Hevroy, 2012) tanggapan 
keluarga pasien penunggu merasa kesepian dan ketidakpastian dikarenakan perawat jarang komunikasi seperti kabur dari pertanyaan keluarga pasien.

Sebuah studi yang dilakukan oleh Dracup dan Bryan-Brown (2005: 2) pada kematian dan sekarat di ICU mengungkapkan bahwa masalah end of life di ICU di antara masalah yang paling serius yang dihadapi Nursing dan profesi medis. Sementara banyak perhatian terfokus pada perawatan kritis peran perawat untuk membantu orang lain pada akhir-of-life atau proses kematian, sedikit perhatian diberikan untuk perawatan perawat kritis psikologis, budaya, dan spiritual kesejahteraan ketika berhadapan dengan masalah kematian dan sekarat atau end-of-life (Naidoo \& MN, 2014).

Dalam melakukan perawatan paliatif di ruang Intensif, perawat sering mengalami konfik keyakinan sebagai penyedia layanan keperawatan mandiri dan advocad bagi pasien, dibandingkan peran perawat sebagai asisten yang hanya melaksanakan tindakan berdasarkan perintah dokter, pengalaman ini sering dialami dan dirasakan oleh perawat (Calvin et al., 2009). Senada penelitian yang dilakukan (Espinosa et al., 2010) menyampaikan perawat mengalami hambatan dalam memberikan asuhan keperawatan di ruang intensive diantaranya kurangnya keterlibatan dalam rencana perawatan, potensial konflik antara model medis dan nursing, perselisihan dokter dengan tim kesehatan lainnya, masalalah pengobatan yang sia-sia pada pasien, harapan yang tidak realistic dari keluarga pasien, dan kurangnya pengalaman dan pendidikan.

Asuhan Keperawatan mempunyai peranan yang sangat penting dalam menciptakan pengalaman untuk menghadapi kematian dengan damai (peaceful end of life). Perawat melakukan pengkajian dan menginterpretasikan isyarat yang mereflesikan pengalaman seseorang dalam menghadapi kematian dan mengintervensi dengan tepat untuk memperoleh atau mempertahankan pengalaman yang damai. Bahkan sekalipun pasien yang akan menghadapi kematian dengan keadaan tidak dapat komunikasi verbal. Menurut salah satu ahli teori keperawatan Shirley M. Moore, teori Peaceful End Of Life, menyatakan bahwa perawat integral akhir dari ketenangan hidup meliputi, kebebasan dari sakit, dukungan emosional, kedekatan dan keikutsertaan pada kenyataan lain yang berpengaruh, dan perlakuan dengan empati dan hormat (Alligood, 2014). 
Perawat perlu memainkan peran dalam memberikan perawatan pada pasien sekarat maupun menjelang kematian di ruang intensif. hal ini dikemukakan (Adams, Bailey, Anderson, \& Docherty, 2011) ada tiga peranan penting dalam perawatan end of life diruang intensif yaitu perantara informasi, supporter, dan advokat.akan tetapi sesuai dengan hasil penelitian sebelumnya yang dipaparkan diatas banyak hal fenomena hambatan perawat dalam memainkan peranannya dalam memberikan asuhan keperawatanya. Banyak penelitian yang dilakukan diluar negeri baik secara kuantitatif maupun kualitatif. Di Indonesia belum ditemukan perenelitian terkait. Penting dilakukan penelitian pengalaman di Indonesia terkait dengan pengalaman perawat dalam memberikan asuhan keperawatan pasien dengan menghadapi kematian diruang Intensif. 


\section{Bab 3}

\section{Metode Penelitian}

Penelitian ini menggunakan metode kualitatif dengan pendekatan fenomenologi, yang bertujuan untuk mendapatkan gambaran tentang pengalaman hidup yang dilihat dari sudut pandang orang yang diteliti (Creswell, 2014). Dalam studi ini yang dipelajari pengalaman perawat intensif dalam memberikan asuhan keperawatan pasien keadaan kritis dan menghadapi kematian pasien intensif. metode ini menitikberatkan pada arti kematian dan keadaan kritis pasien bagi perawat. Sedangkan fenomena yang mendasarinya seringnya perawat diruang intensif terpapar dengan keadaan pasien yang kritis dan menghadapi kematian pasien, menjadi tekanan bagi perawat dalam memberikan asuhan keperawatan. Dengan pendekatan fenomenologi diperoleh gambaran secara menyeluruh tentang perawat dalam menghadapi keadaan kritis dan kematian di ruang intensif. Melalui pendekatan ini juga, peneliti mampu memahami makna dari tindakan perawat dalam menghadapi keadaan kritis dan kematian di ruang intensif.

\section{Partisipan}

Metode dengan fenomenologi memungkinkan peneliti menyeleksi karakteristik partisipan yang heterogen untuk lebih memperdalam pemahaman terhadap fenomena yang diteliti (Afiyanti \& Rachmawati, 2014; Creswell, 2014). Rekrutmen partisipan dilakukan dengan cara purposive sampling (Creswell, 2014). Kreteria penelitian ini adalah:

a. Perawat di ruang intensif yang telah bekerja lebih dari 1 tahun

b. Dapat menceritakan dengan lancar tentang pengalaman selama memberikan asuhan Keperawatan kepada pasien yang menghadapi kematian dan kritis diruang intensif. Streubert \& Carpenter (1999) berpendapat kreteria ini penting dipenuhi oleh partisipan untuk tujuan penyampaian pengetahuan dan informasi tentang fenomena yang ada (Afiyanti \& Rachmawati, 2014)

c. Menjadi perawat tetap di ruang intensif RSU. Dr. Moh. Saleh Probolinggo dan menyatakan kesediaanya untuk ikut terlibat dalam studi ini. 
Focus penelitian kualitatif pada kedalaman dan proses, jumlah partisipan pada penelitian ini 3-15 partisipan sampai terkumpul data yang jenuh atau data yang telah tersaturasi. Semua partisipan dapat berperan serta dari awal pengambilan data sampai selesai penelitian dan tidak ada partisipan yang mengundurkan diri (Creswell, 2014).

Untuk memilih partisipan, peneliti dibantu oleh Kepala Ruangan Intensif. Kepala ruangan bertanggung jawab kepada para calon partisipan untuk menerangkan secara singkat tentang studi ini. Juga menanyakan tentang persetujuan mereka untuk ikut dalam studi ini. Kemudian kepala ruangan memberikan nama-nama calon partisipan dan menunjukan kepada peneliti. Setelah itu peneliti menjalin hubungan kedekatan dengan para calon partisipan dengan melakukan kunjungan di ruangan. Peneliti menerangkan secara terperinci tentang studi yang dilakukan dan meminta persetujuan mereka untuk ikut dalam studi ini termasuk izin merekam. Seluruh pernyataan partisipan dengan mendapatkan tanda tangan mereka pada lembar persetujuan mengikuti penelitian ini. Peneliti menjawab jika terdapat pertanyaan yang diajukan partisipan. Selanjutnya, para partisipan diminta peneliti untuk menentukan waktu dan tempat untuk melakukan wawancara sesuai dengan keinginan mereka dengan tujuan membuat mereka nyaman ketika menceritakan pengalaman-pengalaman mereka.

\section{Proses Pengumpulan Data}

Data dari studi ini dikumpulakan melalui wawancara yang mendalam dengan partisipan. Wawancara formal tidak berstruktur digunakan sebagai metode utama pengumpulan data. Hal ini merupakan metode pengumpulan data yang sesuai dalam studi fenomenologi. Dengan pertanyaan-pertanyaan spesifik dari studi ini yang tidak berstruktur, peneliti dan para partisipan berada pada suatu diskusi yang tidak berstruktur dalam usaha untuk lebih memperjelas suatu arti dari suatu pengalaman (Afiyanti \& Rachmawati, 2014).

Peneliti melakukan wawancara dengan tiap partisipan sebanyak dua kali. Peneliti membantu para partisipan dalam mendiskripsikan pengalaman-pengalaman mereka 
tanpa memimpin diskusi tersebut. untuk meningkatkan akurasi pengumpulan data, peneliti menggunakan teknik wawancara terbuka-tertutup, merekam wawancara, dan membuat transkrip verbatim (kata demi kata). Sebagai tambahan, peneliti juga membuat catatan lapangan (field notes). Sebelum melakukan wawancara, data demografi partisipan dikumpulkan. Informasi ini berguna untuk memberikan gambaran singkat tentang pastisipan. Selain itu juga, peneliti berusaha mensuppresi segala hal yang diketahui dan dialami tentang peran perawat dalam memberikan asuhan keperawatan pasien kondisi kritis (bracketing process).

Wawancara pertama dirancang untuk mendapatkan berbagai perasaan dan pikiran partisipan berkaitan dengan pengalamannya dalam memberikan asuhan keperawatan pada pasien dengan keadaan kritis atau menjelang kematian pasien di ruang intensif. Mula-mula partisipan diberikan kesempatan untuk mendiskripsikan pengalaman-pengalaman mereka tanpa instrupsi. Jika diperlukan, peneliti mengunakan pertanyaan-pertanyaan sesuai pedoman wawancara untuk membantu partisipan lebih memfokuskan aspek-aspek penting dari pengalamannya. Pertanyaan-pertanyaan tersebut dibuat peneliti berpedoman pada berbagai literature yang ada, dan aspek penting untuk mendapatkan suatu pengalaman pribadi seseorang berhubungan dengan studi fenomenologi (van manen, 1997 dalam Afiyanti \& Rachmawati, 2014). Wawancara ini memerlukan waktu sekitar 60-90 menit. Para pastisipan diwawancara secara pribadi dan semua wawancara akan direkam atas izin dari partisipan, lalu hasil wawancara tersebut dibuat dalam bentuk suatu transkrip wawancara yaitu dalam bentuk diskripsi tekstual untuk digunakan dalam analisis data. Selama wawancara peneliti juga membutuhkan untuk mengadopsi perilaku terbuka, berparsipasi, dan memiliki rasa empati kepada partisipan, tujuannya memperoleh berbagai pengetahuan yang nyata dari berbagai pengalaman partisipan dan dapat membantu memberikan bimbingan kepada partisipan dalam mendiskripsikan pengalamannya.

Wawancara kedua dilakukan setelah semua data dari hasil wawancara pertama dibuat dalam suatu transkrip data dan peneliti telah mengidentifikasi kemungkinan berbagai tema sementara dari berbagai pengalaman yang didiskripsikan para 
partisipan. Selama wawancara ini, partisipan diminta untuk mengkonfirmasi tematema yang sementara dihasilkan berhubungan dengan pengalaman mereka berdasarkan hasil interpretasi data yang dibuat peneliti, dan pada kesempatan ini pula peneliti dapat membuat perbaikan atau koreksi jika terdapat gap dari data yang diperoleh pada wawancara pertama. Sebagai tambahan, wawancara kedua juga penting dilakukan untuk memberikan kesempatan pada para partisipan melakukan verifikasi, memperluas dan menambahkan keakuratan data dari studi ini. Pada saat ini pula para partisipan dapat menambahkan deskripsi tentang berbagai pengalaman mereka setelah wawancara pertama. Wawancara kedua memerlukan waktu sekitar 60 menit dan dengan ijin partisipan, semua wawancara kedua direkam.

Untuk kompilasi dan verifikasi data, peneliti mendengarkan hasil rekaman wawancara sambil membacakan hasil transkrip untuk keakuratan dan memberikan koreksi jika terdapat kesalahan. Langkah ini membantu peneliti untuk lebih mengenal diri peneliti sendiri dan memulai untuk menyenangi hasil data ynag telah diperoleh peneliti (Streubert \& Carperter, 1999 dalam Afiyanti \& Rachmawati, 2014).

\section{Analisis Data}

Analisis data dilakukan setiap selesai mengumpulkan data dari satu partisipan. Hasil analisis dapat mengarahkan pada proses selanjutnya. Transkrip-transkrip dari hasil wawancara dan catatan-catatan lapangan (field notes) yang telah dibuat peneliti secara bersamaan dianalisis. Teknik analisis spesifik dengan menggunakan pendekatan analisis selektif dan focusing (the selective or highlighting approach) yang telah di uraikan oleh seorang fenomenologis, Van Manen (1997), telah digunakan dalam analisis studi ini untuk mengungkap dan mengisolasikan berbagai aspek tematik dari fenomena-fenomena yang disoroti dalam studi ini. Teknik ini dimulai dengan mendengarkan bernagai diskripsi verbal partisipan dari hasil rekaman yang diperoleh dan diikuti dengan membaca tiap teks-teks tersebut secara berulang-ulang secara seksama. Setelah itu peneliti mencari, menentukan, dan menggarisbawahi pernyataan-pernyataan atau prase-prase yang signifikan, yang tampaknya menjadi essense-essense spesifik yang mengandung arti dalam mewakili deskripsi para partisipan dari pengalaman atau fenomena memberikan asuhan 
keperawatan kritis diruang intensive. Kemudian peneliti menentukan hubungan tema-tema esensial di antara pernyataan-pernyataan yang signifikan dari pengalaman-pengalaman para partisipannya. Sebagai langkah terakhir, peneliti mempersiapkan tema-tema esensial yang merupakan suatu deskripsi paling terakhir dari fenomena yang terjadi (an exhaustive description of the phenomenom) yang menentukan deskripsi paling sempurna pengalaman-pengalaman para partisipan dalam memberikan asuhan keperawatan pada pasien sekarat dan meghadapi kematian diruang intensif. Alur analisis data dengan teknik analisis spesifik dengan menggunakan pendekatan analisis selektif dan focusing (The selective or highlighting approach) dai vanManen (1997) dalam (Afiyanti \& Rachmawati, 2014). 


\section{DAFTAR PUSTAKA}

Adams, J. a., Bailey, D. E., Anderson, R. a., \& Docherty, S. L. (2011). Nursing Roles and Strategies in End-of-Life Decision Making in Acute Care: A Systematic Review of the Literature. Nursing Research and Practice, 2011, 1-15. doi:10.1155/2011/527834

Afiyanti, Y., \& Rachmawati, I. N. (2014). Metodologi Penelitian Kualitatif dalam Riset Keperawatan (1st ed.). Jakarta: Rajawali Pers.

Alligood, M. R. (2014). Nursing Theorists and Their Work (8th ed.). St. Louis, Missouri: Mosby Elsevier Inc.

Beckstrand, R. L., \& Kirchhoff, K. T. (2005). PROVIDING END - OF -LIFE CARE TO PATIENTS : Critical Care Nurse' Perceived Obstacles and Supportive Behaviors. American Journal of Critical Care, 14(5), 395-403.

Calvin, A. O., Lindy, C. M., \& Clingon, S. L. (2009). The cardiovascular intensive care unit nurse's experience with end-of-life care: a qualitative descriptive study. Intensive \& Critical Care Nursing : The Official Journal of the British Association of Critical Care Nurses, 25(4), 214-20. doi:10.1016/j.iccn.2009.05.001

Elpern, E. H., Covert, B., \& Kleinpell, R. (2005). MORAL DISTRESS OF STAFF NURSES IN A MEDICAL INTENSIVE CARE UNIT. American Journal of Critical Care, 14(6), 523.

Espinosa, L., Young, A., Symes, L., Haile, B., \& Walsh, T. (2010). ICU Nurses ' Experiences in Providing Terminal Care. Critical Care Nurs Q, 33(3), 273-281.

Heyland, D. K., Rocker, G. M., O’Callaghan, C. J., Dodek, P. M., \& Cook, D. J. (2003). Dying in the ICU : Perspectives of family members. Chest, 124(1), 392.

Kirchhoff, K. T., Spuhler, V., Walker, L., Hutton, A., Cole, B. V., \& Clemmer, T. (2000). Intensive care nurses 'experiences with end-of-life care. American Journal of Critical Care, 9(1), 36.

Kirchhoff, K. T., Walker, L., Hutton, A., Spuhler, V., Cole, B. V., \& Clemmer, T. (2002). The vortex : Families ' experiences with death in the intensive care unit. American Journal of Critical Care, 11(May), 200.

Lind, R., Lorem, G. F., Nortvedt, P., \& Hevroy, O. (2012). Intensive care nurses' involvement in the end-of-life process - perspectives of relatives. Nursing Ethics, 19(5), 666-676. doi:10.1177/0969733011433925 
Naidoo, V., \& MN, S. (2014). Experiences of Critical Care Nurses of Death and Dying in an Intensive Care Unit: A Phenomenological Study. Journal of Nursing \& Care, 03(04). doi:10.4172/2167-1168.1000179

Sibbald, R., Downar, J., \& Hawryluck, L. (2007). Perception of "futile care" Among Caregiver in Intensive Care Unit. Canadian Medical Association, 177(10), 1-9.

Smith, R. (2000). A good death. British Medical Jurnal, 320, 129.

Stevens, E., Jackson, S., \& Milligan, S. (2009). Paliative Nursing; Across the Spectrum of Care (first.). Blackwell Publishing Ltd.

Whiteley, S. M., Bodenham, A., \& Bellamy, M. C. (2010). Intensive Care (3rd ed.). elsevier limited. 